\title{
SEJARAH TAFSIR INDONESIA DALAM PERSPEKTIF HISTORY OF IDEA
}

\author{
Masrul Anam \\ Dosen IAIN Kediri \\ Email: anam@iainkediri.ac.id
}

\begin{abstract}
Abstrak
Artikel ini bertujuan untuk memberikan gambaran sejarah perkembangan tafsir karya monumental ulama Indonesia sebelum Indonesia merdeka hingga sekarang, yang belum banyak dieksplorasi oleh para akademisi. Artikel ini berisi pemetaan karya tafsir dari segi geografis, bahasa, tempat lahir dan kemerdekaan. Pertama: segi geografi mengandung arti bahwasannya mufasir itu berdomisili di wilayah Indonesia. Kedua: segi bahasa menunjukkan bahwa kitab tafsir itu menggunakan bahasa Indonesia atau bahasa yang digunakan di Indonesia, seperti bahasa Jawa dan bahasa Sunda dan sebagainya. Ketiga: segi tempat lahir menunjukkan bahwa mufasir itu lahir di wilayah Indonesia walaupun di kemudian hari ia pindah bahkan mungkin menetap di negara lain hingga wafatnya. Keempat: segi kemerdekaan menunjukkan bahwa tafsir itu lahir setelah Indonesia merdeka, yakni tahun 1945 ke atas. Dengan berbagai batasan-batasan ini, akan menjadi mudah dalam memasukkan klasifikasi tafsir yang Indonesia, dan tafsir yang bukan Indonesia.
\end{abstract}

Kata Kunci: sejarah, tafsir Indonesia, history of idea

\section{A. Latar Belakang Masalah}

Indonesia adalah nama sebuah negara kepulauan di Asia Tenggara yang berada di antara benua Asia dan benua Australia. ${ }^{1}$ Negara ini berdiri pada tanggal 17 Agustus 1945 yang ditandai dengan proklamasi kemerdekaan oleh presiden dan wakil presiden pertama Republik Indonesia, Soekarno dan Hatta.

Secara geografis Indonesia merupakan negara yang jauh dari pusat peradaban Islam, namun jumlah pemeluk dan pengaruhnya dalam dunia Islam tidak boleh dianggap remeh. Misalnya keberhasilan umat Muslim Indonesia di dalam melaksanakan rukun Islam yang kelima, yaitu ibadah Haji, berjumlah sebanyak 215.377 orang 529 kelompok terbang (kloter). ${ }^{2}$ Indonesia adalah negara dengan populasi muslim terbesar di dunia. Karena itu Indonesia merupakan negara yang memiliki jumlah kuota jamaah haji terbanyak di dunia. ${ }^{3}$

\footnotetext{
${ }^{1}$ Tim, Kamus Besar Bahasa Indonesia (Jakarta: Balai Pustaka, 2008), 430.

2 https://haji.okezone.com/read/2019/08/06/398/2088641/seluruh-jamaah-haji-indonesiasudah-tiba-di-makkah, diakses 10/02/2019.

${ }^{3}$ https://www.hipwee.com/feature/10-negara-dengan-kuota-haji-terbanyak-meski-indonesiano-1-antriannya-masih-aja-lama-banget/, diakses 2/10/2019.
} 
Selain itu, dari segi bahasa, negara Indonesia bukanlah bagian dari negaranegara Arab, namun minat dan keinginan untuk memperlajari Islam dapat dikatakan sangat tinggi. Terbukti dari sekian banyak negara muslim di dunia, Indonesia memiliki penduduk muslim terbesar.

Dalam wilayah kajian Islam, Indonesia tidak boleh dianggap remeh. Terbukti sepanjang sejarah Indonesia selalu memiliki tokoh ternama dari berbagai disiplin ilmu. Dalam dunia tafsir misalnya, Indonesia memiliki banyak tokoh yang dapat dibanggakan baik dalam ranah lokal maupun internasional.

Tercatat ada banyak tokoh lokal yang mewarnai dunia tafsir di Indonesia. Misalnya Hamka, Quraish Shihab, Hasbi Ash-Siddieqi dan sebagainya. Tokohtokoh tersebut menjadi bukti bahwasannya kajian Islam di Indonesia dapat dikatakan berkembang, khususnya dalam dunia tafsir.

Meskipun tokoh tersebut dapat dikategorikan sebagai penulis tafsir lokal, tetapi kualitas dan argumentasi tafsirnya tidak beda jauh dari tafsir yang berbahasa Arab atau yang berbasis Timur Tengah, meskipun ditulis oleh orang asli Indonesia. Nama-nama tersebut setidaknya menjadi bukti bahwa kajian tafsir di Indonesia tidak boleh dianggap remeh karena selalu ada tokoh tafsir dari masa ke masa.

Selain memiliki tokoh tafsir nasional, Indonesia juga memiliki tokoh tafsir internasional. Misalnya Syaikh Nawawi al-Bantani dengan Marah Labid-nya yang menjadi salah satu rujukan tafsir di Timur Tengah karena bahasa yang digunakannya adalah bahasa Arab. Saat ini, kitab Marah Labid telah masuk kedalam data base al-Maktabah al-Shamilah, sehingga bagi para peneliti dimudahkan untuk mengaksesnya.

Saat ini, kajian tafsir di Indonesia semakin menunjukkan keseriusannya. Hal ini dapat dilihat dari banyaknya literatur tafsir dan kajian tafsir yang ditulis oleh orang Indonesia. Hal ini tidak lain menjadi salah satu alasan pemerintah yang memperhatian tafsir sebagai salah satu khazanah Islam dan layak untuk dikembangkan. Dengan menjamurnya jurusan tafsir di berbagai perguruan tinggi, setidaknya ada wadah resmi dan terstruktur bagi orang-orang yang ingin mendalami dunia tafsir.

Karena banyaknya tokoh tafsir karya buah tangan orang Indonesia dari berbagai daerah yang berbeda-beda, kiranya perlu diadakan kajian komprehensif (luas dan lengkap) terhadap perkembangan sejarah tafsir Indonesia agar para pengkaji dunia tafsir mengetahui lebih jauh tentang perkembangan tafsir di Indonesia sejak pertama kali orang yang menjadi mufasir hingga saat ini.

\section{B. Tentang Indonesia}

\section{Geografis}

Sebelum penulis membahas tentang sejarah perkembangan tafsir di Indonesia, terlebih dahulu penulis perlu membicarakan Indonesia. Hal ini agar tidak terjadi kesalah-pahaman terhadap term tafsir Indonesia. Sebab, jika diteliti lebih jauh, tafsir Indonesia dalam pandangan penulis ada bebarapa kriteria. Pertama, dari segi 


\section{Masrul Anam}

geografis. Kedua, dari segi bahasa. Ketiga, dari segi tempat lahir, dan keempat dari segi kemerdekaan.

Secara geografis, yang disebut Indonesia adalah wilayah yang membentang luas dari Sabang sampai Merauke. Dengan mengetahui batas geografis ini nantinya dapat dipetakan bahwasannya siapapun orang yang menjadi mufasir, asalkan ia berdomisili di wilayah tersebut, maka tafsirnya dapat dikategorikan sebagai tafsir Indonesia.

\section{Bahasa}

Kriteria kedua dari term tafsir Indonesia adalah segi bahasa. Bahasa Indonesia yang resmi telah dibukukan dalam Kamus Besar Bahasa Indonesia. Dengan demikian, kitab tafsir apapun yang menggunakan bahasa Indonesia, dapat dikatakan sebagai tafsir Indonesia, meskipun - jika ada - ditulis oleh orang yang bukan asli Indonesia. Selain itu, dengan menggunakan bahasa Indonesia, maka meniadakan bahasa daerah. Padahal, tidak jarang karya tafsir orang-orang Indonesia yang menggunakan bahasa daerah. Seperti bahasa Jawa dan bahasa Sunda.

\section{Tempat Lahir}

Kriteria ketiga adalah ditinjau dari segi tempat lahir. Hal ini dirasa penting untuk dijadikan sebuah pertimbangan kriteria ke-Indonesiaan. Sebab, tidak jarang seorang tokoh berpindah-pindah dari satu negara ke negara lain sehingga menimbulkan polemik mengenai statusnya. Oleh karena itu, dengan pertimbangan tempat lahir, kiranya bisa dianalisa dan dikategorikan sebagai mufasir Indonesia manakala ia lahir di wilayah Indonesia. Walaupun di kemudian hari mufasir tersebut berpindah negara atau bahkan mungkin menetap di negara lain hingga wafatnya. Seseorang dapat dikategorikan sebagai mufasir Indonesia manakala ia lahir di bumi Indonesia.

\section{Kemerdekaan}

Kategori keempat adalah kemerdekaan. Seperti yang telah maklum diketahui bahwa Indonesia lahir pada tanggal 17 Agustus tahun 1945, ditandai dengan diproklamirkannya kemerdekaan Indonesia oleh presiden dan wakil presiden pertama Indonesia, Soekarno dan Hatta. Kriteria ini dapat digunakan sebagai tolok ukur bahwasannya yang dikatakan Indonesia adalah Indonesia pada tahun $1945 \mathrm{ke}$ atas. Sebab, pada tahun itulah lahirnya bangsa Indonesia.

Dengan berbagai batasan ini, kiranya akan menjadi mudah untuk memetakan mana tafsir yang Indonesia, dan mana tafsir yang bukan Indonesia. Dengan demikian, batasan kemerdekaan ini menjadi salah satu barometer ke-Indonesiaan. Itu artinya, sebelum tahun 1945, belum dapat dikatakan sebagai orang Indonesia.

\section{Kriteria Tafsir}

Sebelum membahas lebih jauh tentang sejarah tafsir Indonesia, perlu kiranya memahami apa yang disebut tafsir. Menurut Ibnu Manzur dalam kamusnya Lisan 
al-'Arab, makna tafsir adalah kashf al-murad 'an lafz al-mushkil ${ }^{4}$ (menyingkap maksud makna suatu lafad yang masih janggal atau sulit dipahami). Sedangkan menurut Badr al-Din Muhammad bin 'Abd Allah bin Bahadir al-Zarkashi (w. 794 H) dalam bukunya al-Burhan fi 'Ulum al-Qur'an arti tafsir adalah 'ilmu yang membahas kitab Allah yang diturunkan kepada Rasulullah Saw dan menjelaskan makna-maknanya, mengeluarkan hukum-hukum, hikmah-hikmah dan semua merujuk dari ilmu bahasa, nahwu, sharaf, ilmu bayan, usul fiqh, dan qira'at-qira'at. Seorang ahli tafsir juga membutuhkan pengetahuan tentang asbab al-nuzul dan nasikh-mansukh. ${ }^{5}$

Sedangkan menurut al-Suyuthi, pengertian tafsir secara bahasa diambil dari wazan taf'il dari kata fasr. Kemudian al-Suyuthi mengutip beberapa pendapat ulama yang mendefiniskan tafsir secara istilah. Menurut Abu Hayyan, tafsir adalah ilmu yang mengkaji cara pengucapan lafad-lafad al-Qur'an, petunjuk-petunjuknya, hukum-hukumnya, baik sebagai kata tunggal atau susunan kalimat dan maknamakna yang mungkin dikandung dalam subuah kalimat dan kesempurnaan semua itu. Selain itu, al-Suyuthi juga menjelaskan pengertian tafsir secara istilah, menurut sebagian ulama, tafsir adalah 'mengetahui turunnya ayat dan segala sesuatu tentangnya, kisah-kisahnya, sebab turunnya, urutan makiyah-madaniyah, yang muhkam dan mutashabih, nasikh-mansukh, amm-khas, mutlaq-muqayyad, mujmalmufassar, halal-haram, janji dan ancamannya, amar-nahi pelajaran darinya dan juga perumpamaannya (tamthil). ${ }^{6}$

Dari pendapat beberapa ulama yang mendefinisikan tafsir di atas, dapat ditarik kesimpulan bahwa semua orang yang berusaha untuk menjelaskan makna alQur'an, ia disebut dengan mufasir. Sebab, ia adalah orang yang menguraikan makna ayat-ayat al-Qur'an. Definisi di atas tidak mengharuskan 'menjelaskan semua ayat dari al-Fatihah hingga al-Nas. Atas dasar inilah, penyusunan tulisan ini bermaksud bahwa semua orang yang melakukan penafsiran al-Qur'an baik sedikit atau banyak dapat dikategorikan sebagai mufasir dan akan dikaji sejarahnya dalam pembahasan berikut ini.

\section{Sejarah Perkembangan Tafsir Indonesia}

Sejarah orang pertama yang menjadi mufasir Nusantara adalah 'Abd Ra'uf bin Ali al-Jawi al-Fansuri al-Sinkili, atau yang sering dikenal dengan sebutan Abd alRa'uf Singkel. Beliau adalah seorang mufasir berkebangsaan Melayu yang lahir di Singkel yaitu daerah pantai barat-laut Aceh pada tahun 1024 H/1615 M dan wafat pada tahun 1693 M. Kitab tafsirnya berjudul Tarjuman al-Mustafid. Kitab ini merupakan kitab tafsir pertama berbahasa Melayu yang paripurna. Oleh karenanya,

\footnotetext{
${ }^{4}$ Ibn Manz\}ur, Lisan al- 'Arab (Kairo: Dar al-Ma'arif al-Misriyah, 1119), 3412-3413.

${ }^{5}$ Badr al-Din Muhammad bin 'Abd Allah bin Bahadir al-Zarkashi, al-Burhan fi 'Ulum alQur'an (Beirut: Dar Ihya' al-Kitab al-'Arabiyah, 1957), Juz 1, 13.

6 'Abd al-Rah\}man bin al-Kamal Jalal al-Din al-Suyuthi, al-Itqan fi 'Ulum al-Qur'an (alMaktabah al-Shamilah al-Isdar Thani), juz 2, 462.
} 
tidak heran jika beliau diberi gelar "Sakaguru Mufasir Nusantara." Selain ahli tafsir, Abdul Ra'uf Singkil juga sebagai tokoh tasawuf di Nusantara. Ia mengajarkan dan menyebarkan tarekat Satariyah yang berasal dari India.

Mufasir Indonesia selanjutnya adalah Abu 'Abd Allah Mu'thi Muhammad Nawawi bin 'Umar. Beliau lahir di Tirtayasa, Serang, Banten, Jawa Barat, pada tahun 1813 M. Beliau wafat pada usia 84 tahun di Makakh al-Mukarramah, tepatnya pada tanggal 25 Syawal 1314 H/1897 M. Kitab tafsirnya berjudul Tafsir al-Munir (Marah Labid). Kitab tafsir ini walaupun karya asli orang Indonesia, akan tetapi bahasa yang digunakan adalah bahasa Arab. Kitab ini terdiri dari dua jilid dan termasuk ke dalam tafsir Ijmali. ${ }^{8}$ Prestasi Shaikh al-Nawawi Banten dapat dikatakan membanggakan, sebab ia memiliki karya tidak kurang dari 115 karya dari berbagai bidang ilmu. Selain itu, ia juga orang Indonesia yang bisa menjadi imam Masjidil Haram. Prestasi yang gemilang dari segi karya, rupanya juga didukung dari segi nasab. Sebab, al-Nawawi juga memiliki nasab sampai kepada Nabi. Ia memiliki nasab sampai kepada Maulana Hasanuddin Putra Sunan Gunung Jati, Cirebon. Keturunan ke-11 dari Sultan Banten. Syaih Nawawi sebagai seorang tokoh dapat dikatakan berhasil dalam mendidik para muridnya. Terbukti dari beberapa muridnya banyak yang menjadi tokoh ternama seperti K.H. Hasyim Asy'ari (Pendiri Nahdlatul Ulama), KH. Ahmad Dahlan (Pendiri Muhammadiyah), KH. Khalil Bangkalan dan sebagainya.

Setelah Shaikh Nawawi, pada tahun 1925 juga muncul karya tafsir Alqoerananoel Hakim Beserta Toejoean dan Maksoednya. Kitab ini adalah karya dua orang yang bernama $\mathrm{H}$. Ilyas dan Abdul Jalil. Tidak berselang lama, pada tahun 1926 juga muncul karya tafsir yakni, Tafsir al-Qur'an al-Karim, yang ditulis oleh Jama' in bin 'Abd al-Murad. Namun Kitab ini hanya menafsirkan juz 1-3. ${ }^{9}$

Mufasir Indonesia masa era selanjutnya adalah Hasan bin Ahmad. Ia adalah keturunan campuran Indonesia-India. Ibunya asli Indonesia sementara ayahnya dari India. Beliau lahir di Singapura pada tahun 1887 M dan tutup usia pada umur 70 tahun di Bangil Pasuruan pada tanggal 10 November 1958. Karya tafsirnya berjudul Tafsir al-Furqan, yang terbit pada tahun 1956 M. Kitab ini menafsirkan al-Quran secara lengkap dari al-Fatihah hingga al-Nas. Prestasi akademiknya dikatakan membanggakan karena adanya pengaruh dari orang tuanya. Orang tua Hasan adalah seorang redaktur majalah Nur al-Islam (sebuah majalah sastra Tamil). Selain sebagai penulis beberapa kitab berbahasa Tamil, al-Hasan juga melakukan beberapa terjemahan dari bahasa Arab. Ibu Ahmad Hasan bernama Muznah, yang berasal dari Palekat Madras, tetapi lahir di Surabaya. Setelah menikah, kedua orang tua Ahmad Hasan menetap di Singapura. Ahmad Hasan, selain ahli tafsir, juga

${ }^{7}$ Saiful Amin Ghafur, Profil Para Mufasir al-Qur'an (Yogyakarta: Pustaka Insan Madani, 2008), 131-134.

${ }^{8}$ Ibid, 190-193. Lihat pula, Muhammad bin 'Amr Nawawi, Marah Labid Likashf Ma'na alQur'an al-Majid (Beirut: Dar al-Kutub al-'Ilmiyah, 1417).

${ }^{9}$ Ibid, 62. 
sebagai pendiri Pondok Pesantren Persis di Bangil, Pasuruan, Jawa Timur. Penyusunan tafsirnya diawali dengan menuliskan tema-tema al-Qur'an atau indeks al-Qur' an lalu baru ditafsirkan mulai surat al-Fatihah hingga surat al-Nas. ${ }^{10}$

Pada tahun tanggal 3 Muharram $1306 \mathrm{H}$, Indonesia memiliki kader baru. Ia bernama KH. Ahmad Sanusi. Sanusi adalah orang Sunda. Sedangkan orang sekitar memanggilnya dengan sebutan Ajengan Sanusi, Ajengan Cantayan, atau Ajengan Genteng. Ia seorang ulama berpengaruh abad 20 di tanah Parahiayangan. Ia dilahirkan pada 3 Muharram 1306, di Cantayan, sebuah desa di Cibadak, Sukabumi, sekitar $20 \mathrm{~km}$ arah Barat kota Sukabumi, Jawa Barat. Ia menulis kitab tafsir berjudul Raudlah al-'Irfan fi Ma'rifah al-Qur'an. Kitab ini merupakan tafsir yang menggunakan bahasa Sunda. ${ }^{11}$ Kitab ini terdiri dari dua jilid. Jilid pertama berisi tafsir juz 1-15 sedangkan jilid kedua berisi tafsir juz 16-30.

Setelah Ahmad Sanusi, pada tahun 1899 Indonesia memiliki mufasir bernama Mahmud Yunus. Mahmud Yunus dilahirkan di Sungayang Batusangkar, Sumatera Barat, pada hari Sabtu 30 Ramadhan $1361 \mathrm{H}$ atau 10 Ferbruari $1899 \mathrm{M}$, dan beliau meninggal pada tanggal 18 Januari 1993 M dalam usia 83 tahun. Mahmud Yunus berpulang ke Rahmatullah di kediamannya di kelurahan Kebon Kosong, Kemayoran, Jakarta Pusat. Kemudian ia dimakamkan di pemakaman UIN Syarif Hidayatullah Jakarta. Kitab tafsirnya berjudul Tafsir al-Qur'an al-Karim. Dari sisi muatannya, tafsir ini termasuk kedalam tafsir Ijmali. ${ }^{12}$ Sementara dari sisi penulisannya, kitab ini ditulis dengan menggunakan bahasa Jawa yang ditulis dengan huruf Arab (pegon). ${ }^{13}$

Pada tahun 1355 H. di Binjai, Langkat Sumatera ada sebuah karya tafsir kolektif berjudul Tafsir al-Qur'an al-Karim yang ditulis oleh tiga orang, yaitu H.A. Halim Hasan, H. Zainal Arifin 'Abbas, dan Abdur Rahim Haitami, namun kitab ini hanya sampai juz ketujuh. ${ }^{14}$ Selain tafsir kolektif, Syaikh Abdul Halim Hasan juga memiliki tafsir karya sendiri dengan judul Tafsir Ahkam. ${ }^{15}$ Syaikh Abdul Halim Hasan, dilahirkan di Binjai, Sumatera Utara, pada tanggal 15 Mei 1901 dan meninggal dunia pada usia 68 tahun 6 bulan, atau bertepatan pada hari Jum'at 14 November 1969. Setelah selesai melaksanakan shalat Jumat di Masjid Raya Binjai, ia bermaksud untuk mengikuti shalat jenazah seorang ustaz M. Rasyid Nur di Masjid Muhammadiyah Binjai. Ketika sedang di perjalanan, tiba-tiba ia

${ }^{10}$ A. Mughni, Syafiq. Hassan Bandung Pemikir Islam Radikal. Surabaya: PT. Bina Ilmu, 1994; Anshari, H.Endang Saifuddin. Ahmad Hassan: Wajah dan Wijhah Seorang Mujtahid dalam buku Abd. Rahman Haji Abdullah. Gerakan Islah di Perlis: Sejarah dan Pemikiran. Kuala Lumpur: Pena SDN.BHD; Djaja, Tamar. Riwayat Hidup A. Hassan. Jakarta: Mutiara, 1980. Juga Hasan, Ahmad. Tafsir Al-Furqan. Surabaya: Al-Ikhwan, 1986.

${ }^{11}$ Ibid, 193-199

${ }^{12}$ Ibid, 199-200.

${ }^{13}$ Islah Gusmian, Khazanah Tafsir Indonesia: Dari Hermeneutika hingga Ideologi (Jakarta: Teraju, 2003), 49.

${ }^{14}$ Ibid, 59.

${ }^{15}$ Binjai, Abdul Halim Hasan. Tafsir al-Ahkam. Jakarta: Kencana, 2006. 
jatuh sakit dan langsung dibawa ke Rumah Sakit PNP II Bangkatan Binjai hingga pulang kerahmatullah.

Pada awal abad ke-20, Indonesia melahirkan mufasir baru. Ia adalah Hasbie Ash-Shiddieqy. Beliau lahir pada tanggal 10 Maret 1904 di Lhoukseumawe Aceh Utara. Al-Hajj Teungku Qadhi Chik Maharaja Mangkubumi Husein ibn Muhammad Mas'ud dan Teungku Amrah adalah nama orang tuanya. Ayah Hasbie adalah seorang ulama terkenal yang memiliki sebuah dayah (pesantren), sementara ibunya adalah puteri Teungku Abdul Aziz, pemangku jabatan Qadhi Chik Maharaja Mangkubumi Kesultanan Aceh waktu itu. Ia merupakan keturunan Abu Bakar AshShiddiq yang ketiga puluh tujuh. Oleh sebab itu gelar Ash-Shiddiq dijadikan nama keluarganya. Ketika berusia 6 tahun, ibunya meningggal dunia. Sejak itu ia diasuh oleh bibinya, Teungku Syamsiah. Beliau menulis dua kitab tafsir, yaitu Tafsir alNur (1953) dan Tafsir al-Bayan (1966). Untuk tafsir al-Nur, pertama kali terbit pada tahun 1956. Penulisan tafsir dengan menggunakan bahasa non-Arab masih menjadi polemik pada saat itu. Mengingat peraturan pemerintah Arab Saudi yang mengharamkan penulisan tafsir al-Qur'an dengan bahasa 'Ajam (non-Arab). Namun ia tetap konsisten bahwa gagasannya tersebut adalah baik bagi umat Islam. Akhirnya penulisan tafsir tersebut dapat selesai. Sementara untuk Tafsir al-Bayan berjumlah empat jilid dengan ketebalan 1749 halaman. ${ }^{16}$

Setelah masa Hasbie, pada tahun 1953 M muncul pula karya tafsir yang ditulis oleh dua orang, yaitu Zainudin Hamidi dan Fahrudin Hs. Dengan nama Tafsir alQur'an, yang kemudian terbit pertama kali pada tahun $1959 .{ }^{17}$ Haji Zainuddin Hamidy lahir di Koto Nan IV Payakumbuh pada tanggal 8 Februari 1907. Anak dari Abdul Hamid dan Halimah. Putra kedua dari dua orang bersaudara. Kakaknya bernama Nahrawi, istri Imam Mukhtasar, seorang ulama terpandang di daerahnya. Dia memiliki 5 orang saudara sebapak, seperti Zainullah, Amiruddin, Salim, Mariam, dan Bermawi. Masa kecil dihabiskan Zainuddin Hamidy di kampung halamannya. Abdul Hamid, ayahnya terkenal sebagai seorang berilmu, terutama ilmu agama yang mendalam, maupun ilmu bela diri silat. Beliau memiliki sifat percaya diri yang tinggi, pemberani dan suka menolong orang lain. Ia sering menghadapi preman pasar yang suka memeras dan menganiaya masyarakat lemah. Karena keberanian dan kepiawaiannya dalam bela diri inilah masyarakat memberikan julukan padanya dengan orang bagak (orang yang pemberani). $\mathrm{H}$. Zainuddin Hamidy wafat pada hari jum'at tanggal 29 Maret 1997.

Nama mufasir Indonesia yang cukup terkenal selanjutnya adalah Haji Abd alMalik Karim Amrullah, atau sering disebut dengan Buya Hamka. Beliau lahir di Kampung Molek Maninjau, Sumatera Barat pada tahun 1908 M dan meninggal dunia pada tanggal 24 Juli 1981 di Jakarta. Karier intelektual Hamka tidak diragukan lagi sebab ia adalah tokoh yang memiliki gelar profesor. Selain itu, dalam wilayah politik, Hamka juga pernah menjabat sebagai salah satu petinggi di

\footnotetext{
${ }^{16}$ Ibid, 207-208.

${ }^{17}$ Gusmian, Khazanah Tafsir., 60.
} 
Kementrian Agama RI. Selain prestasi akademik dan politik, Hamka aktif dalam organisasi Muhammadiyah dan terpilih menjadi ketua Majlis Pimpinan Muhammadiyah di Sumatera Barat oleh Konferensi Muhammadiyah, menggantikan S.Y. Sutan Mangkuto pada tahun 1946. Pada tahun 1953, Hamka dipilih sebagai penasihat pimpinan Pusat Muhammadiah. Pada 26 Juli 1977 Hamka juga pernah menjabat sebagai ketua Majelis Ulama Indonesia (MUI) yang dilantik oleh Prof. Dr. Mukti Ali. Karya tafsir yang ditulis oleh Hamka adalah Tafsir alAzhar. Kitab ini termasuk kedalam kelompok Tahlili yakni menguraikan ayat dengan panjang lebar. Karena penjelasan yang panjang ini, maka wajar jika tafsir ini menjadi 15 jilid. $^{18}$

Di Jawa pada tahun 1915 M lahir seorang tokoh tafsir bernama Bisri Mustafa. Ia lahir di kampung Sawahan, Rembang, Jawa Tengah, pada tahun 1915 M, dan wafat pada tanggal 17 Februari 1977 M. KH Bisri Musthofa merupakan satu di antara sekian ulama Indonesia yang memiliki karya besar. Beliau adalah pengarang kitab tafsir al-Ibriz li Ma'rifah Tafsir al-Qur'an al-'Aziz. Kitab tafsir bimakna pesantren ini selesai beliau tulis pada tahun 1960. Karya-karya beliau tak sebatas pada bidang tafsir, di bidang lain pun juga ada, seperti tauhid, fiqh, tasawuf, hadist, tata bahasa Arab, sastra, dan sebagainya. Sedangkan karya monumentalnya dalam bidang tafsir adalah Tafsir Ibriz. Kitab ini adalah tafsir bahasa Jawa yang ditulis dengan huruf Arab pegon. ${ }^{19}$ Kitab tafsir karya Bisri Mustafa ini sekarang memiliki beberapa versi. Ada yang satu jilid ${ }^{20}$ dan ada pula yang 30 jilid berdasarkan juz al-Qur'an. Jadi, setiap satu jilid satu juz al-Qur'an.

Setelah era tafsir al-Ibriz, sekitar tahun 1930-an terdapat sebuah tafsir yang berjudul Tafsir al-Qur'an Hidjatur Rahman, karya Munawwar Khalil. Kitab ini ditulis dengan bahasa Jawa. ${ }^{21}$ Mengenai informasi kitab ini, penulis tidak menemukan secara rinci. Hanya sebatas informasi dari Islah Gusmian saja.

Pada tahun 1981 terbit sebuah tafsir yang berjudul Tafsir Rahmat, karya Oemar Bakri. Karya ini juga menambah daftar karya tafir Nusantara. Kitab ini terbit pertama kali pada tahun 1981 dan lengkap menafsirkan al-Qur'an hingga 30 juz. ${ }^{22}$ Haji Oemar Bakry lahir di desa Kacang Sumatra Barat 26 Juni 1916. Ia menempuh pendidikan dasarnya di SD Kacang dan sekolah sambungan di Singkarak. Ia meneruskan ke sekolah Tawalib dan Diniyah Putra Padang Panjang. Tamat di Diniyah 1931 dan Thawalib 1932. Kemudian melanjutkan pada sekolah Kuliyatul Mualimin Islamiyah Padang, lulus pada tahun 1936 dengan nilai terbaik. Kemudian melanjutkan ke fakultas Sastra Universitas Indonesia, namun tidak sampai lulus. Nama Oemar Bakry semakin mencuat dan dikenal oleh masyarakat luas, terutama ketika mengomentari karya H.B.Yasin Al-Qur'anul Karim Bacaan

${ }^{18}$ Ibid, 210-212. Lihat pula, Hamka, Tafsir al-Azhar (Pembimbing Masa, 1968). Lihat pula terbitan Malaysia, Hamka, Tafsir aal-Azhar (Selangor, Publising House, 2015).

${ }^{19}$ Ibid, 215-216.

${ }^{20}$ Bisri Mustafa, al-Ibriz li Ma'rifah Tafsir al-Qur'an al- 'Aziz. (Wonosobo: Lensa Indonesia).

${ }^{21}$ Gusmian, Khazanah Tafsir., 50.

${ }^{22}$ Ibid, 60. 
Mulia pada tahun 1978. Ditinjau dari segi karir, Oemar Bakry pernah menjadi pimpinan Masyumi Sumatera Tengah. Selain itu, ia juga seorang pengusaha percetakan dan pernah menjadi ketua IKAPI (Ikatan Percetakan Indonesia) Jakarta Raya beberapa periode, ketua Yayasan al-Falah, Yayasan Pemeliharaan Kesucian al-Qur'an al-Karim, dan yayasan Thawalib Jakarta. Pimpinan penerbit Angkasa di Jakarta dan Mutiara di Bandung.

Pada tahun 1972-1976 Rektor ke-4 UIN Sunan Kalijaga Yogyakarta (IAINdulu), Drs. Purn. H. Bakri Shahid, menulis tafsir berjudul Tafsir al-Huda. Karya ini merupakan tafsir berbahasa Jawa yang kental dengan nuansa ke-Indonesiaan. Selain itu, H. Bakri juga pernah menjabat sebagai rektor pertama Universitas Muhammadiyah Yogyakarta. ${ }^{23}$

Karya tafsir Indonesia selanjutnya adalah Tafsir Iklil karya Misbah Mustafa yang menggunakan bahasa Jawa. KH. Misbah adalah seorang pengasuh Pondok Pesantren al-Balagh, Bangilan, Tuban, Jawa Timur. Ia dilahirkan di pesisir utara Jawa Tengah, tepatnya di kampung Sawahan, Gang Palem, Rembang pada tahun 1916 dengan nama Masruh. Ia lahir dari pasangan keluarga Zaenal Musthafa dan Khadijah. Ayahnya dikenal masyarakat sebagai orang yang taat beragama, di samping sebagai pedagang yang sukses dalam usaha menjual batik-batik yang berkualitas. Oleh karena itu, keluarga Masruh dikenal sebagai keluarga yang cukup berada secara ekonomi untuk ukuran saat itu, di saat ekonomi Indonesia umumnya sangat memperihatinkan sebagai dampak adanya imperialisme politik dan ekonomi pihak penjajah. Keberangkatan Masruh bersama orangtua dan seluruh anggota keluarga menunaikan ibadah Haji merupakan indikator yang menunjukkan kemampuan ekonomi orangtuanya. Sepulangnya dari menunaikan ibadah Haji tersebut, Masruh kemudian mengganti namanya dengan Misbah Musthafa. Ia adalah adik kandung Bisri Mustafa yang memiliki karya tafsir al-Ibriz.

Pada saat ini, Indonesia memiliki tokoh tafsir bernama Muhammad Hatta dengan karyanya Tafsir al-Qur'an Perkata: Dilengkapi dengan Terjemah dan Asbabun Nuzulnya. Buku ini dapat dikatakan tafsir yang sederhana namun sangat mudah untuk dipelajari. Sebab, setiap ayat yang memiliki sebab turun, dalam buku ini dapat diketahui. Tafsir ini hanya berjumlah satu jilid namun juga lengkap menafsirkan al-Qur'an 30 juz, namun dengan cakupan yang sangat sempit karena hanya berbasis penafsiran perkata, kata-kata sulit dan juga sebab turunnya alQur'an. Selain itu, dalam tafsir ini juga dilengkapi dengan indeks al-Qur'an berupa tema-tema tertentu seperti sosial, agama, politik, pendidikan dan sebagainya. ${ }^{24}$

Saat ini Indonesia juga memiliki mufasir bernama Muhammad Quraish Shihab. Beliau adalah tokoh tafsir Indonesia ternama. Ia lahir di Rapang, Sulawesi Selatan

\footnotetext{
${ }^{23} \mathrm{https}$ ://id.wikipedia.org/w/index.php?title=Bakri_Syahid\&action=edit\&section=1, dan juga dalam situs https://id.wikipedia.org/w/index.php?title=Bakri_Syahid\&action=edit\&section=2 Dikakses tanggal 26 September 2017. Lihat pula dalam penelitian oleh Imam Muhsin, al-Qur'an dan Budaya Jawa dalam Tafsir al-Huda Karya Bakri Syahid (Yogyakarta: Elsaq Press, 2013).

${ }^{24}$ Muh \}ammad Hatta, Tafsir al-Qur'an Perkata: Dilengkapi dengan Terjemah daan Asbabun Nuzul (Jakarta: Maghfirah Pustaka, 2009).
} 
pada tanggal 16 Februari 1944. Karya monumentalnya adalah Tafsir al-Misbah: Pesan, Kesan dan Keserasian al-Qur'an. Kitab ini terdiri dari 15 jilid, yang lengkap 30 juz dan runtut berdasarkan mushaf. ${ }^{25}$ Selain itu, Quraish Shihab juga memiliki tafsir kedua yang berjudul $a l-L u b a b$. Kitab ini terdiri dari 4 jilid dan lengkap menafsirkan al-Qur'an 30 juz.

Indonesia saat ini juga memiliki mufasir kontroversial. Ia bernama Dawam Raharjo. Ia lahir di Solo pada tanggal 20 April 1942 M. Dawam Raharjo adalah lulusan dari Fakultas Ekonomi Universitas Muhammadiyah Malang. Meskipun ia banyak dikenal sebagai seorang ahli ekonomi, ia juga mencoba menuliskan alQur'an yang dinilainya bisa didekati dengan berbagai disiplin ilmu. Ia menuliskan Ensiklopedia Al-Qur'an, Tafsir Sosial Berdasarkan Konsep-konsep Kunci. ${ }^{26}$ Banyak kalangan yang keberatan terhadap tulisannya jika dimasukkan kedalam kategori 'tafsir', akan tetapi diakui atau tidak, sesungguhnya upaya dia dalam berkarya tersebut perlu diapresiasi, sebab para pengkaji ilmu-ilmu al-Qur'an dan tafsir sekalipun belum tentau bisa memiliki karya seperti dia.

Di Indonesia sebenarnya ada banyak tokoh yang menuliskan tafsir singkat, baik berdasarkan tema atau hanya menafsirkan satu surat saja. Jalal al-Din Rahmat misalnya menuliskan Tafsir Sufi al-Fatihah, Didin Hafifuddin menuliskan tafsir hasil pengajiannya dengan judul Tafsir Hijri yang berdasarkan tema. Nasaruddin Umar yang gigih memperjuangkan gender menuliskan disertasinya dengan judul Perspektif Gender dalam al-Qur'an, yang kemudian dibukukan dengan judul Argumen Kesetaraan Gender, Perspektif al-Qur'an. ${ }^{27}$ Kyai Asmuni Petuk Semen Kediri juga memiliki karya tafsir yang berjudul Tafsir Mu'awidhatain, Tafsir Surah al-Qadr dan juga Tafsir al-Fatihah. Khusus kitab Tafsir al-Fatihah, kitab ini menjelaskan tentang, nama-nama, perihal turunnya, dan keutamaan Fatih \}ah serta menjelaskan tentang masalah-masalah fikih juga menjelaskan tentang isti'adhah dan basmalah. ${ }^{28}$. Selain para mufasir yang tertera di atas, penulis berasumsi bahwa masih banyak karya tafsir singkat yang belum dipublikasikan, terutama bagi kyaikyai pondok pesantren yang memang memiliki tafsir tersendiri untuk kalangan dalam.

\section{Daftar Pustaka}

'Abd al-Rahman bin al-Kamal Jalal al-Din al-Suyuti, al-Itqan fi 'Ulum alQur'an, al-Maktabah al-Shamilah al-Isdar Thani.

Ahmad bin Ashmuni al-Jarauni, Muqaddimah Tafsir al-Fatih $\} a h$, Kediri: Ma'had al-Islamiyyah al-Hidayah al-Tulab, tt.

25 Ibid, 236-240. Lihat pula, M. Quraish Shihab, Tafsir al-Misbah: Pesan Kesan dan Keserasian al-Qur'an (Jakarta: Lentera Hati, 2005).

${ }^{26}$ Ibid, 219-220

${ }^{27}$ Ibid, 223-233.

28 Ahmad bin Ashmuni al-Jarauni, Muqaddimah Tafsir al-Fatihah (Kediri: Ma'had alIsla>miyyah al-Hidayah al-Tulab, $\mathrm{tt}$ ). 


\section{Masrul Anam}

Badr al-Din Muhammad bin 'Abd Allah bin Bahadir al-Zarkashi, al-Burhan fi 'Ulum al-Qur'an, Beirut: Dar Ihya' al-Kitab al-'Arabiyah, 1957.

Binjai, Abdul Halim Hasan. Tafsir al-Ahkam, Jakarta: Kencana, 2006.

Bisri Mustafa, al-Ibriz li al-Ma'rifah Tafsir al-Qur'an al- 'Aziz, Wonosobo: Lensa Indonesia.

Djaja, Tamar. Riwayat Hidup A. Hassan, Jakarta : Mutiara, 1980.

Hamka, Tafsir aal-Azhar, Selangor, Publising House, 2015.

Hasan, Ahmad. Tafsir Al-Furqan, Surabaya : Al-Ikhwan, 1986

https://haji.okezone.com/read/2019/08/06/398/2088641/seluruh-jamaah-hajiindonesia-sudah-tiba-di-makkah.

https://id.wikipedia.org/w/index.php?title=Bakri_Syahid\&action=edit\&section=1, https://id.wikipedia.org/w/index.php?title=Bakri_Syahid\&action=edit $\underline{\& \text { section }=2}$.

https://www.hipwee.com/feature/10-negara-dengan-kuota-haji-terbanyak-meskiindonesia-no-1-antriannya-masih-aja-lama-banget/.

Ibn Manzur, Lisan al- 'Arab, Kairo: Dar al-Ma'arif al-Misriyah, 1119.

Imam Muhsin, al-Qur'an dan Budaya Jawa dalam Tafsir al-Huda Karya Bakri Syahid, Yogyakarta: Elsaq Press, 2013.

Islah Gusmian, Khazanah Tafsir Indonesia: Dari Hermeneutika hingga Ideologi, Jakarta: Teraju, 2003.

M. Quraish Shihab, Tafsir al-Misbah: Pesan Kesan dan Keserasian al-Qur'an, Jakarta: Lentera Hati, 2005.

Muhammad bin 'Amr Nawawi, Marah Labid Likashf Ma'na al-Qur'an alMajid, Beirut: Dar al-Kutub al-'Ilmiyah, 1417.

Muhammad Hatta, Tafsir al-Qur'an Perkata: Dilengkapi dengan Terjemah daan Asbabun Nuzul, Jakarta: Maghfirah Pustaka, 2009.

Saiful Amin Ghafur, Profil Para Mufasir al-Qur'an, Yogyakarta: Pustaka Insan Madani, 2008.

Syafiq, A. Mughni, Syafiq. Hassan Bandung Pemikir Islam Radikal, Surabaya : PT. Bina Ilmu, 1994. 